\title{
The role of positron emission tomography/computed tomography in the evaluation of anterior mediastinal masses and differentiating between the histological subtypes of thymic epithelial neoplasms
}

\author{
Anterior mediastinal kitlelerin değerlendirilmesinde ve timik epitelyal neoplazilerin \\ histolojik alt tip ayrımında pozitron emisyon tomografi/bilgisayarlı tomografinin rolü
}

\author{
Ahmet Yanarateş (D), Emine Budak (i) \\ Department of Nuclear Medicine, University of Health Sciences, Izmir Dr. Suat Seren Chest Diseases and Surgery \\ Training and Research Hospital, Izmir, Turkey
}

\begin{abstract}
Background: This study aims to investigate the role of positron emission tomography/computed tomography in differentiating between benign and malignant anterior mediastinal masses and between the histological subtypes of thymic epithelial neoplasms.

Methods: This retrospective study included a total of 57 patients (30 males, 27 females; mean age 48.9 years; range, 14 to 78 years) who underwent an fluorodeoxyglucose positron emission tomography/ computed tomography with an indication of an anterior mediastinal mass between May 2010 and November 2018. The maximum and mean standardized uptake values, metabolic tumor volume, total lesion glycolysis, and mean Hounsfield units of the lesions were determined. Thymic epithelial neoplasms were classified as low-risk thymomas (A, AB, B1), high-risk thymomas (B2, B3), and thymic carcinomas. All lesions were evaluated together and divided into two groups as benign and malignant, and positron emission tomography/computed tomography parameters of the two groups were compared.
\end{abstract}

Results: Histopathological examination identified 29 thymic epithelial neoplasms (13 low-risk, 14 high-risk, two thymic carcinomas), 13 benign lesions, and 15 malignant lesions. No significant correlation was identified between the positron emission tomography/computed tomography parameters and histological subtype of thymic epithelial neoplasms. There was no significant difference in the maximum and mean standardized uptake values, metabolic tumor volume, total lesion glycolysis, and mean Hounsfield units of the lesions between low-risk and high-risk thymic carcinomas. The maximum and mean standardized uptake values, metabolic tumor volume, and mean Hounsfield units of the lesions were significantly higher in the malignant group than in the benign group.

Conclusion: Our study results show that positron emission tomography/ computed tomography is useful in the differentiation of benign and malignant anterior mediastinal masses, although it fails to differentiate between the histological subtypes of thymic epithelial neoplasms.

Keywords: Anterior mediastinal mass, fluorodeoxyglucose, maximum standardized uptake value, metabolic tumor volume, positron emission tomography/computed tomography, thymic epithelial neoplasm.
$\ddot{O} Z$

Amaç: Bu çalışmada anterior mediastinal kitlelerin benign/ malign ayrımında ve timik epitelyal neoplazilerin histolojik alt tip ayrımında pozitron emisyon tomografi/bilgisayarlı tomografinin rolü araştırıldı.

Çalışma planı: Bu retrospektif çalışmaya Mayıs 2010 - Kasım 2018 tarihleri arasında anterior mediastinal kitle endikasyonu ile florodeoksiglukoz pozitron emisyon tomografi/bilgisayarlı tomografi çekilen toplam 57 hasta (30 erkek, 27 kadın; ort. yaş 48.9 yıl; dağılım, 14-78 y1l) dahil edildi. Lezyonların maksimum ve ortalama standardize tutulum değerleri, metabolik tümör volümü, total lezyon glikolizi ve ortalama Hounsfield birimi belirlendi. Timik epitelyal neoplaziler düşük riskli timomalar (A, AB, B1), yüksek riskli timomalar (B2, B3) ve timik karsinomlar olmak üzere sınıflandırıldı. Tüm lezyonlar bir arada değerlendirildi, benign ve malign olmak üzere iki gruba ayrıldı ve bu iki grubun pozitron emisyon tomografi/bilgisayarlı tomografi parametreleri karşılaştırıldı.

Bulgular: Histopatolojik incelemede 29 timik epitelyal neoplazi (13 düşük riskli, 14 yüksek riskli ve iki timik karsinom), 13 benign lezyon ve 15 malign lezyon saptand. Pozitron emisyon tomografi/ bilgisayarlı tomografi parametreleri ve timik epitelyal neoplaziler arasında anlamlı bir ilişki tespit edilmedi. Düşük riskli ve yüksek riskli timik karsinomlar arasında maksimum ve ortalama standardize tutulum değerleri, metabolik tümör volümü, total lezyon glikolizi ve ortalama Hounsfield birimi açısından anlamlı bir fark yoktu. Lezyonların maksimum ve ortalama standardize tutulum değerleri, metabolik tümör volümü ve ortalama Hounsfield birimi benign gruba kıyasla malign grupta anlamlı düzeyde daha yüksekti.

Sonuç: Çalışma sonuçlarımız, pozitron emisyon tomografi/bilgisayarlı tomografinin benign ve malign anterior mediastinal kitlelerin ayrımında kullanışlı olduğunu; ancak, timik epitelyal neoplazilerin histolojik alt tiplerinin ayrımında yetersiz kaldı̆̆ını göstermektedir.

Anahtar sözcükler: Anterior mediastinal kitle, florodeoksiglukoz, maksimum standardize tutulum değeri, metabolik tümör volümü, pozitron emisyon tomografi/ bilgisayarlı tomografi, timik epitelyel neoplazi.

Received: June 29, 2019 Accepted: November 11, 2019 Published online: March 06, 2020

Correspondence: Ahmet Yanarateş, MD. Sağlık Bilimleri Üniversitesi, İzmir Dr. Suat Seren Göğüs Hastalıkları ve Cerrahisi Eğitim ve Araştırma Hastanesi, Nükleer Tıp Kliniği, 35170 Konak, İzmir, Türkiye. Tel: +90 505 - 9580405 e-mail: ahmetyanarates@gmail.com 
The mediastinum contains several fundamental components and cystic, infectious and neoplastic lesions of different origins may arise. The majority of mediastinal tumors are benign lesions, and it has been shown that lesions in the anterior mediastinum have a higher probability of being malignant. ${ }^{[1]}$ Thymic neoplasms are the most common lesions in the anterior mediastinum. ${ }^{[2]}$

In the 2004 World Health Organization (WHO) classification system, thymic epithelial neoplasms (TENs) are divided into three groups according to their histological characteristics as low-risk thymomas (LRT; types $\mathrm{A}, \mathrm{AB}$ and $\mathrm{B} 1$ ), high-risk thymomas (HRT; types B2 and B3), and thymic carcinomas. ${ }^{[3]}$ The Masaoka staging, which is another classification system, is based on the invasion, dissemination, and metastatic characteristics of the mass lesion. ${ }^{[4]}$ The WHO classification, Masaoka stage, tumor diameter, and complete resection are considered as prognostic factors for TENs. ${ }^{[3]}$

The accurate identification of benign and malignant lesions, and the determination of appropriate treatment methods are of particular importance in the management of mediastinal masses. Computed tomography (CT) and magnetic resonance imaging (MRI) scans describe characteristics features for mediastinal masses, ${ }^{[5-8]}$ although such findings may be insufficient to accurately differentiate between benign and malignant lesions..$^{[9-12]}$ It has been also demonstrated that $\mathrm{CT}$ is of limited value in differentiating between the 2004 WHO histological subtypes of TENs. ${ }^{[13]}$ The fluorodeoxyglucose (FDG) positron emission tomography (PET)/CT, which is a commonly used method in the oncology practice, is also utilized in the differential diagnosis of mediastinal masses.

There is a limited number of studies in the literature evaluating the role of PET/CT in the differentiation of anterior mediastinal masses. ${ }^{[14-16]}$ Morita et al. ${ }^{[14]}$ suggested that PET/CT could be used to differentiate between benign and malignant lesions. Kim et al. ${ }^{[3]}$ reported that FDG PET or PET/CT findings were useful for identifying the histological subtypes of TENs. In the present study, we aimed to investigate the role of FDG PET/CT in the differentiation of benign and malignant anterior mediastinal masses and to identify the correlation between the histological subtypes of TENs and PET/CT parameters.

\section{PATIENTS AND METHODS}

This retrospective study was conducted at the Department of Nuclear Medicine of Dr. Suat Seren Chest
Diseases and Chest Surgery Training and Research Hospital between May 2010 and November 2018. A total of 57 patients ( 30 males, 27 females; mean age 48.9 years; range, 14 to 78 years) who underwent an FDG PET/CT with an indication of an anterior mediastinal mass were included. Patients who underwent surgery or treatment prior to PET/CT examination were excluded. A histopathological diagnosis was made in all patients. The patients with a TEN were classified according to the 2004 WHO classification criteria as LRT (types A, AB, B1), HRT (types B2, B3), and thymic carcinoma.

A written informed consent was obtained from each patient. The study protocol was approved by Izmir Tepecik Training and Research Hospital Ethics Committee (Date: 27.06.2019-No. 2019/10-1). The study was conducted in accordance with the principles of the Declaration of Helsinki.

\section{FDG PET/CT imaging procedure}

After six hours of fasting, 8-11 $\mathrm{mCi}$ FDG was injected intravenously into the patients with a blood glucose level of less than $200 \mathrm{mg} / \mathrm{dL}$. Images were captured one hour after the injection using a Philips Gemini TF 16 Slice PET/CT scanner (Philips Medical Systems, Cleveland, OH, USA). First, CT images $(140 \mathrm{kV}, 100 \mathrm{mAs}, 5 \mathrm{~mm}$ slice) of the patients were obtained from the vertex of the skull to the upper femur, after which, PET scans of the same fields were obtained (1.5 $\mathrm{min} / \mathrm{bed}$ position). The CT and PET images were uploaded to the workstation, and the CT images were used for attenuation correction.

An isocontour three-dimensional region of interest (ROI) was drawn to include the mass lesion observed in the anterior mediastinum on PET/CT. The maximum standardized uptake value (SUV) of the pixel within the ROI was determined as $\mathrm{SUV}_{\max }$. As a recommended value, $41 \%{ }^{[17]} \mathrm{SUV}_{\max }$ was taken as the threshold for the calculation of the $S_{U V} V_{\text {mean }}$ and metabolic tumor volume (MTV). The total lesion glycolysis (TLG) was calculated by multiplying the MTV by the SUV mean. Additionally, the mean Hounsfield units (HU) of the primary lesion were noted.

\section{Histopathological findings and statistical analysis}

A histopathological diagnosis was performed in all patients. A statistical analysis was performed in three stages in the present study. The first two stages involved TENs. As malignancy potential gradually increases after type $\mathrm{A}$ in TENs which are classified according to the WHO classification (A, AB, B1, B2, B3, thymic carcinomas), the histological subtype was considered as 
Table 1. Anterior mediastinal lesions according to histological subtypes

\begin{tabular}{lcc}
\hline & $\mathrm{n}$ & $\%$ \\
\hline All lesions & & \\
TENs & 29 & 50.8 \\
Thymus & 4 & 7 \\
Thymic cyst & 4 & 7 \\
Thymic hemangioma & 1 & 1.7 \\
Cavernous hemangioma & 1 & 1.7 \\
Mediastinitis & 1 & 1.7 \\
Ectopic thyroid & 1 & 1.7 \\
Castleman's disease & 1 & 1.7 \\
Non-Hodgkin lymphoma & 7 & 12.2 \\
Hodgkin lymphoma & 5 & 8.7 \\
Germ cell tumor & 1 & 1.7 \\
Chronic lymphocytic leukemia & 1 & 1.7 \\
Sarcoma & 1 & 1.7 \\
TENs (WHO) & & \\
Type a & 2 & 6.8 \\
Type ab & 1 & 3.4 \\
Type b1 & 10 & 34.4 \\
Type b2 & 7 & 24.1 \\
Type b3 & 7 & 24.1 \\
Thymic carcinoma & 2 & 6.8 \\
\hline
\end{tabular}

TENs: Thymic epithelial neoplasms; WHO: World Health Organization.

a continuous variable. A Spearman's rho test was used to evaluate the correlation between the histological subtype and the $\mathrm{SUV}_{\max }, \mathrm{SUV}_{\text {mean }}, \mathrm{MTV}$, TLG, and HU values. In the second stage, TENs were classified as LRT (types A, AB, B1), HRT (types B2, B3) and thymic carcinomas, and the mean $\mathrm{SUV}_{\max }, \mathrm{SUV}_{\text {mean }}$ TLG, MTV and HU values were compared among the groups. Normally distributed variables were analyzed using a one-way analysis of variance (ANOVA), and variables without normal distribution were analyzed using the Kruskal-Wallis test. In the third stage, all lesions were evaluated together and divided into two groups as benign or malignant. At this stage, LRT was included in the benign group and HRT and thymic carcinomas were included in the malignant group. We calculated the sensitivity, specificity, and accuracy of PET/CT for detecting malignancy using a $\mathrm{SUV}_{\max }$ cut-off value of 3. Also, the $\mathrm{SUV}_{\max }, \mathrm{SUV}_{\text {mean }}$, TLG, MTV, and HU values of the groups were compared using a t-test. A receiver operating characteristic (ROC) curve was created to identify the optimal cutoff value for the differentiation of benign lesions from malignant lesions. A $p$ value of $<0.05$ was considered statistically significant.

Overall survival (OS), defined as the length of time from the date of diagnosis to the date of death, was also recorded using the Death Registry System (MERNIS), or to the date of last admission, if the patient survived. The survival curve of patients with LRT and HRT was drawn using the Kaplan-Meier method and compared using the log-rank test.

\section{RESULTS}

All patients included in the study had an anterior mediastinal mass. Histopathological examination identified 29 thymic epithelial neoplasms. According to the WHO classification, 13 patients had a LRT (type $\mathrm{A}=2$, type $\mathrm{AB}=1$, type $\mathrm{B} 1=10$ ), 14 had a HRT (type $\mathrm{B} 2=7$, type $\mathrm{B} 3=7$ ), and two had a thymic carcinoma. In addition, 13 patients had a benign lesion $(n=4$ delayed thymic involution, $n=4$ thymic cyst, $\mathrm{n}=1$ thymic hemangioma, $\mathrm{n}=1$ cavernous hemangioma, $n=1$ mediastinitis, $n=1$ ectopic thyroid tissue, and $n=1$ Castleman disease), 15 patients had a malignant lesion $(n=7$ non-Hodgkin lymphoma, $n=5$ Hodgkin lymphoma, $n=1$ germ cell tumor, $n=1$ chronic lymphocytic leukemia, and $n=1$ soft tissue sarcoma). The results are summarized in Table 1.

Correlation analysis revealed no significant correlation between the increasing malignancy potential from type $A$ to thymic carcinoma and $\mathrm{SUV}_{\max }$, SUV mean, MTV, TLG, and HU values ( $p>0.05$ for all). In addition, when TENS were further divided into three groups as LRT $(n=13)$, HRT $(n=14)$ and thymic carcinoma $(n=2)$, there was no significant difference between the groups in terms of $\mathrm{SUV}_{\max }$ $(\mathrm{p}=0.297), \mathrm{SUV}_{\text {mean }}(\mathrm{p}=0.227), \mathrm{MTV}(\mathrm{p}=0.649), \mathrm{TLG}$ $(\mathrm{p}=0.484)$, and HU $(\mathrm{p}=0.085)$ (Table 2).

Table 2. Comparison of PET/CT parameters between subgroups of TENs

\begin{tabular}{|c|c|c|c|c|c|c|c|c|c|c|c|}
\hline & $\mathrm{n}$ & $\mathrm{SUV}_{\max }$ & $p$ & $\mathrm{SUV}_{\text {mean }}$ & $p$ & MTV & $p$ & TLG & $p$ & $\mathrm{HU}$ & $p$ \\
\hline LRT & 13 & $6.5 \pm 3.6$ & & $3.8 \pm 1.7$ & & $88.7 \pm 64.1$ & & $347.8 \pm 277.6$ & & $26.1 \pm 6.8$ & \\
\hline HRT & 14 & $8 \pm 7.5$ & 0.297 & $4.1 \pm 2.4$ & 0.227 & $111.1 \pm 134$ & 0.649 & $659.5 \pm 1425$ & 0.484 & $25.7 \pm 10$ & 0.085 \\
\hline Thymic ca & 2 & $16.4 \pm 12$ & & $6.8 \pm 3.5$ & & $109.8 \pm 41$ & & $820.5 \pm 671.5$ & & $41 \pm 8.4$ & \\
\hline
\end{tabular}

PET: Positron emission tomography; CT: Computed tomography; TENs: Thymic epithelial neoplasms; SUV $\max$ : Maximum standardized uptake value, SUV $\mathrm{V}_{\text {mean: }}$ Mean standardized uptake value; MTV: Metabolic tumor volume; TLG: Total lesion glycolysis; HU: Hounsfield unit; LRT: Low-risk thymoma; HRT: High-risk thymoma; Thymic ca: Thymic carcinoma. 
Table 3. Comparison of PET/CT parameters between benign and malignant groups

\begin{tabular}{lccccccccccc}
\hline & $\mathrm{n}$ & $\mathrm{SUV}_{\max }$ & $p$ & $\mathrm{SUV}_{\text {mean }}$ & $p$ & $\mathrm{MTV}$ & $p$ & $\mathrm{TLG}$ & $p$ & $\mathrm{HU}$ & $p$ \\
\hline Benign & 26 & $4.3 \pm 3.5$ & & $2.6 \pm 1.8$ & & $57.4 \pm 62.4$ & & $1846 \pm 8425$ & $0.037 *$ & 788 & $15 \pm 18$ \\
Malign & 31 & $10.2 \pm 8.5$ & & $4.001 * 2.9$ & & $114 \pm 129.4$ & & $773 \pm 1463$ & & $25.6 \pm 9.9$ & $0.011 *$ \\
\hline
\end{tabular}

PET: Positron emission tomography; CT: Computed tomography; TEN: Thymic epithelial neoplasm; $S_{\text {U }}$ max: Maximum standardized uptake value, SUV $V_{\text {mean }}$ Mean standardized uptake value; MTV: Metabolic tumor volume; TLG: Total lesion glycolysis; HU: Hounsfield unit; * Significant values at p<0.05.

All lesions were divided into two groups as benign (LRT and benign) or malignant (HRT, thymic carcinoma and malignant). When a $S U V_{\max }$ cut-off value of 3 was used, PET/CT was true positive in 29 , true negative in 12 , false positive in 14 , and false negative in two of the mediastinal masses. The sensitivity, specificity, and accuracy of PET/CT in detecting malignancy were $93.5 \%, 46.1 \%$, and $71.9 \%$, respectively.

Furthermore, the mean $\mathrm{SUV}_{\max }(\mathrm{p}=0.001)$, $\operatorname{SUV}_{\text {mean }}(\mathrm{p}=0.001), \operatorname{MTV}(\mathrm{p}=0.037)$ and HU $(\mathrm{p}=0.011)$ values were significantly higher in the malignant group than in the benign group. However, TLG $(\mathrm{p}=0.488)$ did not differ significantly between the two groups (Table 3 ). When the ROC curve was drawn to differentiate between the malignant and the benign groups (Figure 1), an optimum cut-off value was unable to be determined for MTV (area under the

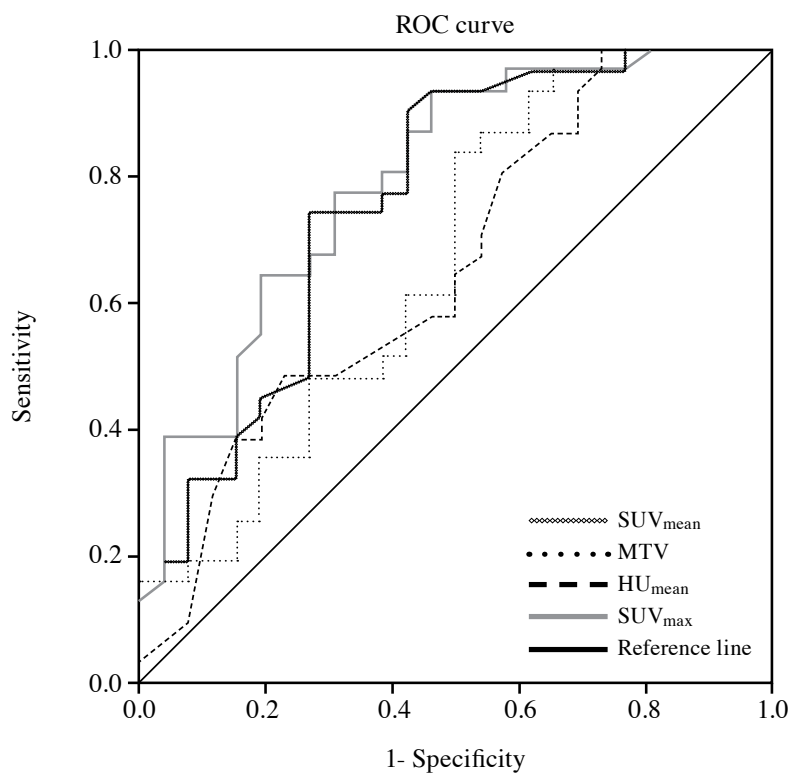

Figure 1. The ROC curves of PET/CT parameters. The area under the curve of $\mathrm{SUV}_{\max }, \mathrm{SUV}_{\text {mean }}, \mathrm{MTV}$, and $\mathrm{HU}$ were 0.795 , $0.765,0.665$, and 0.656 , respectively.

ROC: Receiver operating characteristic; SUV $\mathrm{max}_{\max }$ Maximum standardized uptake value; MTV: Metabolic tumor volume; HU: Hounsfield unit; SUV $V_{\text {mean }}$ : Mean standardized uptake value; PET: Positron emission tomography; CT: Computed tomography. curve $[\mathrm{AUC}]=0.665)$ or $\mathrm{HU}(\mathrm{AUC}=0.656)$, as the $\mathrm{AUC}$ was relatively low. The optimum cut-off values for $\mathrm{SUV}_{\max }$ and $\mathrm{SUV}_{\text {mean }}$ were $4.6(77 \%$ sensitivity and $70 \%$ specificity, $\mathrm{AUC}=0.795)$ and $3.1(74 \%$ sensitivity and $74 \%$ specificity, AUC $=0.765$ ), respectively. Two samples of the benign and malignant groups are presented in Figures 2 and 3.

The OS of all patients was calculated, and 10 of 57 patients were found to have died at the time of analysis. The final diagnoses of the patients with anterior mediastinal masses including benign lesions were

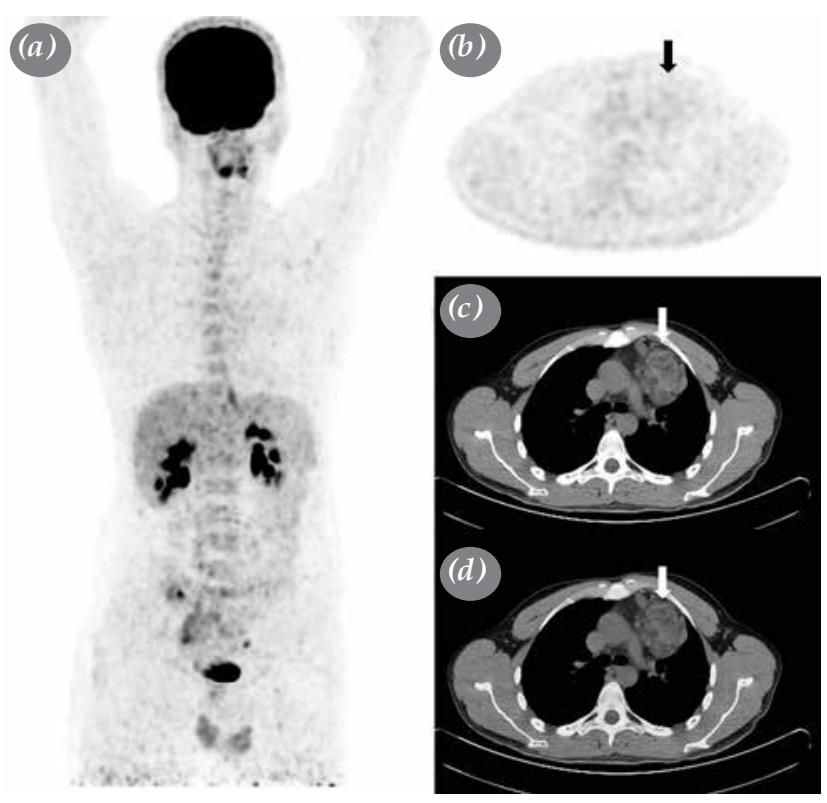

Figure 2. The MIP (a), PET (b), CT (c), and fusion (d) images of a 25-year-old male patient whose anterior mediastinal mass was confirmed histopathologically to be a cavernous hemangioma are shown. The SUV $V_{\text {max }}, \mathrm{SUV}_{\text {mean }}, \mathrm{MTV}$, TLG, and mean HU values of primary lesion (arrows) on PET/CT were found to be 2.1, 1.1, $87.4 \mathrm{~mL}, 96.1 \mathrm{~g}$, and -2 , respectively. It would be reasonable to assume that the relatively large dimensions of the lesion with significantly low SUV values was the cause of high MTV and TLG values.

MIP: Maximum intensity projection; PET: Positron emission tomography; CT: Computed tomography; $\mathrm{SUV}_{\max }$ : Maximum standardized uptake value; $\mathrm{SUV}_{\text {mean }}$ : Mean standardized uptake value; MTV: Metabolic tumor volume; TLG: Total lesion glycolysis; HU: Hounsfield unit. 

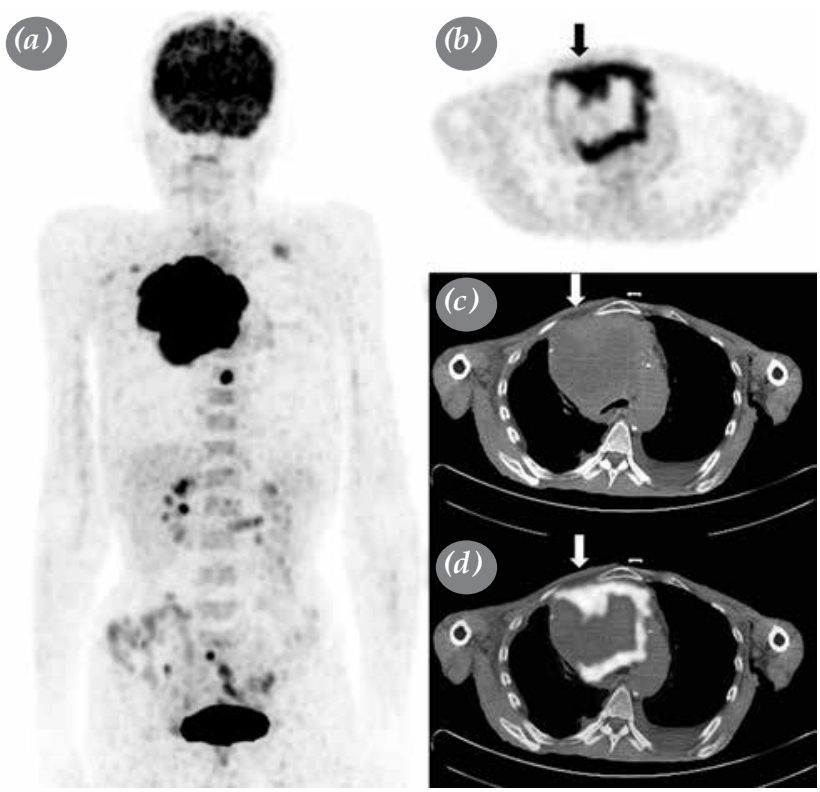

Figure 3. The MIP (a) and selected axial PET (b), CT (c), and fusion (d) images are shown. The SUVmax, SUVmean, MTV, TLG, and mean HU values of the primary lesion (arrows) on PET/CT in a 63-year-old male patient with a diagnosis of highrisk thymoma (type B3) were found to be 31.5, 10.6, $525.1 \mathrm{~mL}$, $5,566 \mathrm{~g}$, and 9, respectively. The mean HU value of the tumor was found to be relatively low, compared to the other lesions in the malignant group, and the clear cause of this was the necrotic component of the lesion.

MIP: Maximum intensity projection; PET: Positron emission tomography; CT: Computed tomography; $\mathrm{SUV}_{\max }$ : Maximum standardized uptake value; $\mathrm{SUV}_{\text {mean }}$ : Mean standardized uptake value; MTV: Metabolic tumor volume; TLG: Total lesion glycolysis; HU: Hounsfield unit.

heterogeneous and, also, there was a small number of patients in each group. A survival analysis was performed for the LRT $(n=13)$ and HRT $(n=14)$ groups which included the highest number of patients, and two patients in the LRT group and five patients in the HRT group were found to have died at the time of analysis. The mean survival was $37.3 \pm 4.2$ (range, 1 to 44 ) months in the LRT group and $62.2 \pm 14$ (range, 1 to 103) months in the HRT group, indicating no significant difference between the groups $(\mathrm{p}=0.277)$.

\section{DISCUSSION}

A the mediastinum contains numerous vital tissue structures, masses may occur in association with a congenital malformation, or may originate from other causes, such as traumatic, cystic, infectious or neoplastic factors. Several studies have demonstrated that anterior mediastinal mass lesions account for more than half of all mediastinal lesions (54 to $57 \%$ ). ${ }^{[1,18]}$ Although benign lesions account for the majority of mediastinal tumors, anterior mediastinal masses have a higher probability of being malignant. ${ }^{[1]}$ In a study, the rate of malignancy among mediastinal masses was found to be $59 \%$ in the anterior mediastinum, $29 \%$ in the middle mediastinum, and $16 \%$ in the posterior mediastinum, and the overall rate of malignancy was reported to be $42 \%$, considering the mass lesions in all compartments. ${ }^{[1]}$ Carter et al ${ }^{[2]}$ reported that the mass lesions in the anterior mediastinum were composed of thymic neoplasms (35\%), lymphoma (25\%), thyroid and other endocrine tumors (15\%), benign teratomas $(10 \%)$, malignant germ cell tumors $(10 \%)$, and benign thymic lesions (5\%). Consistent with literature, the most common anterior mediastinal mass lesions in the present study were TENs $(50.8 \%)$, followed by lymphomas $(21 \%)$.

Typically, TENs are divided into three groups as LRT (types A, AB and B1), HRT (types B2 and B3), and thymic carcinomas, based on the World Health Organization (WHO) classification system which was first introduced in 1999 and modified to its final version in 2004. ${ }^{[3]}$ The malignancy potential of TENs increases gradually as from type A lesions. ${ }^{[19]}$ Thymomas are the most common type of TENs. Thymomas type $\mathrm{A}$ and $\mathrm{AB}$ often behave like benign tumors and type B1 behaves like a lowgrade malignant tumor (10-year survival rates of over 90\%). ${ }^{[19]}$ Type B2 thymomas have a higher degree of malignancy than LRT, and advanced stage type B3 thymomas are associated with poor prognosis as are thymic carcinomas and malignant tumors of the other organs. ${ }^{[19]}$

In the clinical practice, PET/CT, which is used to diagnose, stage, and evaluate response to treatment for many malignancies, is also used to evaluate mediastinal masses. The role of PET/CT in differentiating between benign and malignant masses of the anterior mediastinum has been investigated in several studies. In the study by Morita et al., ${ }^{[14]}$ the mean $\mathrm{SUV}_{\max }$, MTV, and TLG values of malignant mediastinal tumors, including HRTs and thymic carcinomas, were found to be significantly higher than those of benign tumors, including LRTs. The optimal cut-off values for $\mathrm{SUV}_{\max }, \mathrm{MTV}$, and TLG in differentiating between benign and malignant mediastinal tumors were identified to be 4.2, 22.3 and 79.7, respectively. In another study, Kubota et al. ${ }^{[15]}$ found a significantly higher mean FDG uptake in malignant tumors than in benign tumors and identified an approximate 3.5 differential uptake ratio as the cut-off value in the differentiation of malignant tumors. Thymomas were classified as invasive and non-invasive in the study by 
Kubota et al., ${ }^{[15]}$ with invasive thymomas and thymic carcinomas considered malignant and non-invasive thymomas considered benign. Although $\mathrm{SUV}_{\max }$ has no definitive diagnostic value, it has been reported that the $\mathrm{SUV}_{\max }$ value above 2.5-3 in mediastinal lesions strengthens the likelihood of malignancy. ${ }^{[20]}$ When a SUV $_{\max }$ cut-off value of 3 was used in the present study, the sensitivity, specificity, and accuracy of PET/CT in detecting malignancy were $93.5 \%, 46.1 \%$, and $71.9 \%$, respectively. Furthermore, the $\mathrm{SUV}_{\max }, \mathrm{SUV}_{\text {mean }}$, MTV and HU values were found to be significantly higher in the malignant group than in the benign group in our study, and the optimal cut-off values for $S U V_{\max }$ and $S U V_{\text {mean }}$ were 4.6 and 3.1, respectively. Based on these findings, the presence of low-density lesions, such as cysts and hemangiomas, in the benign group is thought to be the reason for the difference between the two groups in terms of HU values. Our study results are mostly consistent with the literature. However, we were unable to find no significant difference between the benign and malignant groups in terms of TLG values. The MTV and TLG are volumetric parameters, and TLG is derived from multiplying the MTV value by the $S U V_{\text {mean. }}$ Tumor size was not included in the statistical analysis, although larger lesions were present among the benign lesions. This may have contributed to the failure of the TLG value in the differentiation of benign and malignant lesions. Also, different optimal cut-off values were identified in previous studies which can be attributed to discrepancies in the patient populations.

In the literature, there are many studies investigating the role of PET parameters in the differentiation of thymic lesions, although most of these studies have included a small number of patients with a retrospective study design. In a study of 20 patients with thymic mass lesions who were divided into benign and malignant (LRTs, HRTs, thymic carcinomas) groups based on the histopathological examination, Travaini et al. ${ }^{[1]}$ found significantly lower SUV values in benign lesions than in HRTs and malignant lesions. In a prospective study of 23 thymic lesions, a significant difference was found in the mean $\mathrm{SUV}_{\max }$ of thymic hyperplasia (1.1), thymoma (2.3), and thymic carcinoma (7.0), although there was no significant difference between LRTs (3.0) and HRTs (2.1). ${ }^{[22]}$ In a study of 33 patients with TENs, Sung et al. ${ }^{[23]}$ reported significantly lower $\mathrm{SUV}_{\max }$ in LRTs and HRTs than in thymic carcinomas. In another study of 36 patients with TENs, the $S_{U V} V_{\text {peak }} /$ medistinal $\mathrm{SUV}_{\text {mean }}(\mathrm{T} / \mathrm{M})$ ratio of the tumor in the LRT, HRT, and thymic carcinoma groups was compared, and the T/M ratio was found to be lower in
LRT than in HRT, and lower in HRT than in thymic carcinoma group. ${ }^{[24]}$ A study of 46 patients with TENs using dual-phase PET/CT imaging suggested that an early $\mathrm{SUV}_{\max }$ of $>4.5$ could be used as a cut-off value in the differentiation of HRT+thymic carcinomas from LRTs, and that a cut-off value of $>7.1$ could be used to differentiate between thymic carcinomas and HRT+LRT. ${ }^{[25]}$ In a study by Igai et al. ${ }^{[26]}$ involving 13 patients with TENs, the mean $\mathrm{SUV}_{\max }$ of thymic carcinomas was found to be significantly higher than that of thymomas $(8.2 \pm 7.9$ vs. $3.4 \pm 2.2)$. Although the mean $\mathrm{SUV}_{\max }$, MTV, and TLG values of thymic carcinomas were found to be significantly higher than those of thymomas in the study by Morita et al., ${ }^{[14]}$ no significant difference was found between the LRT and HRT groups. In the present study, we observed no significant correlation between the increasing potential of malignancy in TENs and the $\mathrm{SUV}_{\max }$, $\mathrm{SUV}_{\text {mean }}, \mathrm{MTV}, \mathrm{TLG}$, and HU values. There was also no significant difference between the PET/CT parameters, when TENs were categorized into three groups as LRTs, HRTs, and thymic carcinomas. The majority of previous studies reported higher PET parameters in thymic carcinomas than in thymomas, while our study found no significant difference in this regard. A possible explanation for this may be relatively small number of patients with thymic carcinoma $(n=2)$ in our study. Of note, there are conflicting data in the literature regarding the value of PET parameters in the differentiation of the LRT and HRT thymoma subtypes, and a possible cause for this may be the partial volume effect resulting from the small size of some lesions in HRTs. As mentioned previously, previous studies in this field have tended to involve a small patient population and to have a heterogeneous character. The Masaoka stage and tumor diameter, which have prognostic value in TENs, were not taken into consideration in most studies, and the lack of standardization in the patient population may have contributed to the different results.

The present study has several limitations, such as the retrospective study design and the relatively small sample size.

In conclusion, our study results show that positron emission tomography/computed tomography is useful in the differentiation of benign and malignant anterior mediastinal masses, although it fails to differentiate between the histological subtypes of thymic epithelial neoplasms. In addition, the fact that the present study evaluates also volumetric positron emission tomography parameters is believed to contribute to the limited data in the literature. 


\section{Declaration of conflicting interests}

The authors declared no conflicts of interest with respect to the authorship and/or publication of this article.

\section{Funding}

The authors received no financial support for the research and/or authorship of this article.

\section{REFERENCES}

1. Davis RD Jr, Oldham HN Jr, Sabiston DC Jr. Primary cysts and neoplasms of the mediastinum: recent changes in clinical presentation, methods of diagnosis, management, and results. Ann Thorac Surg 1987;44:229-37.

2. Carter BW, Marom EM, Detterbeck FC. Approaching the patient with an anterior mediastinal mass: a guide for clinicians. J Thorac Oncol 2014;9:S102-9.

3. Kim JY, Kim HO, Kim JS, Moon DH, Kim YH, Kim DK, et al. (18)F-FDG PET/CT is Useful for Pretreatment Assessment of the Histopathologic Type of Thymic Epithelial Tumors. Nucl Med Mol Imaging 2010;44:177-84.

4. Masaoka A, Monden Y, Nakahara K, Tanioka T. Follow-up study of thymomas with special reference to their clinical stages. Cancer 1981;48:2485-92.

5. Strollo DC, Rosado de Christenson ML, Jett JR. Primary mediastinal tumors. Part 1: tumors of the anterior mediastinum. Chest 1997;112:511-22.

6. Strollo DC, Rosado-de-Christenson ML, Jett JR. Primary mediastinal tumors: part II. Tumors of the middle and posterior mediastinum. Chest 1997;112:1344-57.

7. Landwehr P, Schulte O, Lackner K. MR imaging of the chest: mediastinum and chest wall. Eur Radiol 1999;9:1737-44.

8. Whitten CR, Khan S, Munneke GJ, Grubnic S. A diagnostic approach to mediastinal abnormalities. Radiographics 2007;27:657-71

9. Ahn JM, Lee KS, Goo JM, Song KS, Kim SJ, Im JG. Predicting the histology of anterior mediastinal masses: comparison of chest radiography and CT. J Thorac Imaging 1996;11:265-71.

10. Link KM, Samuels LJ, Reed JC, Loehr SP, Lesko NM. Magnetic resonance imaging of the mediastinum. J Thorac Imaging 1993;8:34-53.

11. Gamsu G, Stark DD, Webb WR, Moore EH, Sheldon PE. Magnetic resonance imaging of benign mediastinal masses. Radiology 1984;151:709-13.

12. Tomiyama N, Honda O, Tsubamoto M, Inoue A, Sumikawa $\mathrm{H}$, Kuriyama K, et al. Anterior mediastinal tumors: diagnostic accuracy of CT and MRI. Eur J Radiol 2009;69:280-8.

13. Jeong YJ, Lee KS, Kim J, Shim YM, Han J, Kwon OJ. Does CT of thymic epithelial tumors enable us to differentiate histologic subtypes and predict prognosis? AJR Am J Roentgenol 2004;183:283-9.

14. Morita T, Tatsumi M, Ishibashi M, Isohashi K, Kato H, Honda $\mathrm{O}$, et al. Assessment of Mediastinal Tumors Using
SUVmax and Volumetric Parameters on FDG-PET/CT. Asia Ocean J Nucl Med Biol 2017;5:22-9.

15. Kubota K, Yamada S, Kondo T, Yamada K, Fukuda H, Fujiwara $\mathrm{T}$, et al. PET imaging of primary mediastinal tumours. Br J Cancer 1996;73:882-6.

16. Luzzi L, Campione A, Gorla A, Vassallo G, Bianchi A, Biggi A, et al. Role of fluorine-flurodeoxyglucose positron emission tomography/computed tomography in preoperative assessment of anterior mediastinal masses. Eur J Cardiothorac Surg 2009;36:475-9.

17. Boellaard R, O'Doherty MJ, Weber WA, Mottaghy FM, Lonsdale MN, Stroobants SG, et al. FDG PET and PET/ CT: EANM procedure guidelines for tumour PET imaging: version 1.0. Eur J Nucl Med Mol Imaging 2010;37:181-200.

18. Cohen AJ, Thompson L, Edwards FH, Bellamy RF. Primary cysts and tumors of the mediastinum. Ann Thorac Surg 1991;51:378-84.

19. Travis WD, Brambilla E, Müller-Hermelink HK, Harris CC. Pathology and Genetics of Tumours of the Lung, Pleura, Thymus and Heart. World Health Organization Classification of Tumours. Lyon: IARC Press; 2004. p. 145-67.

20. Öztaş S, Öztürk AV, Acartürk E, Tezel Y, Özdemir M, Ataç $\mathrm{G}$, et al. The role of tumor SUVmax/lymph node SUVmax ratio viewed on PET-CT in the detection of mediastinal metastasis in patients with lung cancer. Turk Gogus Kalp Dama 2012;20:544-51.

21. Travaini LL, Petralia G, Trifirò G, Ravasi L, Galetta D, Carbone G, et al. [18F]FDG positron emission tomography/ computed tomography and multidetector computed tomography roles in thymic lesion treatment planning. Lung Cancer 2008;61:362-8.

22. Kumar A, Regmi SK, Dutta R, Kumar R, Gupta SD, Das P, et al. Characterization of thymic masses using (18)F-FDG PET-CT. Ann Nucl Med 2009;23:569-77.

23. Sung YM, Lee KS, Kim BT, Choi JY, Shim YM, Yi CA. 18F-FDG PET/CT of thymic epithelial tumors: usefulness for distinguishing and staging tumor subgroups. J Nucl Med 2006;47:1628-34.

24. Endo M, Nakagawa K, Ohde Y, Okumura T, Kondo H, Igawa $\mathrm{S}$, et al. Utility of 18FDG-PET for differentiating the grade of malignancy in thymic epithelial tumors. Lung Cancer 2008;61:350-5.

25. Inoue A, Tomiyama $N$, Tatsumi $M$, Ikeda $N$, Okumura M, Shiono H, et al. (18)F-FDG PET for the evaluation of thymic epithelial tumors: Correlation with the World Health Organization classification in addition to dual-time-point imaging. Eur J Nucl Med Mol Imaging 2009;36:1219-25.

26. Igai H, Matsuura N, Tarumi S, Chang SS, Misaki N, Go $\mathrm{T}$, Ishikawa $\mathrm{S}$, et al. Usefulness of [18F]fluoro-2-deoxyD-glucose positron emission tomography for predicting the World Health Organization malignancy grade of thymic epithelial tumors. Eur J Cardiothorac Surg 2011;40:143-5. 